\title{
Seasonal activity of Dinoponera quadriceps Santschi (Formicidae, Ponerinae) in the semi-arid Caatinga of northeastern Brazil
}

\author{
Jeniffer Medeiros ${ }^{1}$, Arrilton Araújo ${ }^{1}$, Helder F. P. Araújo², João Paulo C. Queiroz ${ }^{3} \&$ Alexandre Vasconcellos ${ }^{3}$
}

'Laboratório de Biologia Comportamental, Universidade Federal do Rio Grande do Norte, 59072-970 Natal-RN, Brazil. jeniffercm@gmail.com; arrilton@gmail.com

2Departamento de Ciências Biológicas, Universidade Federal da Paraíba, 58397-000 Areia-PB, Brazil. hfparaujo@yahoo.com.br

${ }^{3}$ Laboratório de Termitologia, Departamento Sistemática e Ecologia, Universidade Federal da Paraíba, 58051-900 João Pessoa-PB, Brazil.

pauloecologo@yahoo.com.br; avasconcellos@dse.ufpb.br

\begin{abstract}
Seasonal activity of Dinoponera quadriceps Santschi (Formicidae, Ponerinae) in the semi-arid Caatinga of northeastern Brazil. We studied seasonal foraging patterns of the queenless ant $D$. quadriceps (Formicidae, Ponerinae) for 24 months in a Caatinga area of northeastern Brazil, an ecosystem characterized by strong climatic changes throughout the year, in order to determine if regulation of worker activity is based on environmental conditions (air temperature, relative humidity, precipitation) and/or food resources (potential prey: Coleoptera, Diptera, Hemiptera, Hymenoptera, Lepidoptera, Orthoptera, Araneae, Chilopoda and Diplopoda). Foraging activity of $D$. quadriceps varied over the course of both years, with the highest frequency occurring from May to August, corresponding to the late rainy season and early dry season. This foraging activity was negatively correlated with temperature and positively correlated with the availability of potential prey, but not with total abundance of soil arthropods or with rainfall and relative humidity. Diet composition, in relation to the main taxonomic prey groups, seems to be common to the species, regardless of habitat. Our results suggest that $D$. quadriceps workers adjust foraging activity to the most suitable period of the year, to avoid thermal stress and increase efficiency. Thus, they present an appropriate behavioral response to seasonal fluctuations in the Caatinga.
\end{abstract}

KEYWORDS. Ants; environmental factors; foraging; Neotropical region, seasonality.

RESUMO. Atividade sazonal de Dinoponera quadriceps Santschi (Formicidae, Ponerinae) em caatinga semiárida do nordeste brasileiro. Foi estudado o padrão de forrageamento da formiga sem rainha D. quadriceps (Formicidae, Ponerinae) durante 24 meses em uma área de caatinga do nordeste brasileiro, um ecossistema caracterizado pelas fortes mudanças climáticas ao longo do ano, com objetivo de determinar se a atividade das operárias é regulada pelas condições ambientais (temperatura do ar, umidade relativa, precipitação) e/ou recursos alimentares (presas potenciais: Coleoptera, Diptera, Hemiptera, Hymenoptera, Lepidoptera, Orthoptera, Araneae, Chilopoda e Diplopoda). A atividade de forrageamento de D. quadriceps variou ao longo dos dois anos, com a maior freqüência ocorrendo de maio a agosto, correspondendo ao final da estação chuvosa e início da estação seca. Essa atividade de forrageamento foi negativamente relacionada com a temperatura e positivamente relacionada com a disponibilidade de presas potenciais. Não houve relação com a abundância total de artrópodes de solo, precipitação e umidade relativa. A composição da dieta, em relação aos grupos taxonômicos das presas, parece ser comum à espécie, independente do habitat. Os resultados sugerem que as operárias de $D$. quadriceps ajustam sua atividade de forrageamento ao longo do ano para evitar estresse térmico e aumentar sua eficiência. Desta forma, elas possuem uma resposta comportamental apropriada para a flutuação sazonal da Caatinga.

PALAVRAS-CHAVE. Fatores ambientais; forrageamento; formigas; região Neotropical; sazonalidade.

Ants adopt a wide variety of foraging strategies. Workers search for food individually or in groups, with intermediate strategies between the two extremes (Beckers et al. 1989). Nevertheless, whatever the type of foraging adopted by ants, their foraging activity levels throughout the year depend on many factors that vary seasonally, such as temperature (Abril et al. 2007; Domisch et al. 2009; Dunn et al. 2007; Pol \& Lopez de Casenave 2004; Vogt et al. 2003), humidity (Fotso Kuate et al. 2008; Levings 1983) and food availability (Cogni \& Oliveira 2004; Peeters \& Crewe 1987; Raimundo et al. 2009). Because ants are ectothermic, temperature and hydric stress are physical factors that may affect energetic costs of foraging, limiting activity outside the nest to suitable periods (Levings 1983; Traniello 1989). An adjustment of foraging intensity to resource availability in the environment may occur in species in which there is no recruitment due to in- creasing rates of successful capture of food items, positively influencing the degree of nest departure of other foragers (Raimundo et al. 2009; Schafer et al. 2006). These seasonal changes in the environment affect foraging activity of each species differently, depending on their physical tolerance level, ecological needs and competitive capacity (Barrow \& Parr 2008).

Few studies have investigated foraging in Dinoponera quadriceps Santschi (Formicidae, Ponerinae)(Araújo \& Rodrigues 2006), although the absence of a queen caste has stimulated numerous studies on reproduction and dominance hierarchy in this species (Dantas de Araújo et al. 1990a, 1990b; Hart \& Ratnieks 2005; Monnin et al. 1998, 2002, 2003; Monnin \& Peeters 1998, 1999; Monnin \& Ratnieks 1999; Peeters et al. 1999). The species is endemic to the Neotropical region of Brazil, with occurrences recorded in the 
Atlantic Forest, Caatinga and Cerrado areas (Kempf 1971; Paiva \& Brandão 1995). D. quadriceps nests are located on the ground, up to a depth of around one meter, with an average of eight chambers, ranging up to 16 , and one or more entrances (Dantas de Araújo et al. 1990b; Paiva \& Brandão 1995; Vasconcellos et al. 2004). Such a variation in both number of chambers and entrances seems to be related to colony size (Morgan, 1993; Vasconcellos et al. 2004). Their colonies can contain up to 140 workers, with an average population per nest of more than fifty workers, in addition to abundant offspring (Dantas de Araújo et al. 1990a; Monnin \& Peeters 1998; Paiva \& Brandão 1995; Vasconcellos et al. 2004). Workers carry dead organic matter, mainly arthropods, back to the nest. Only on rare occasions are live prey captured. Small fruits and seeds also form a part (about 30\%) of the D. quadriceps diet. Thus, although they are often considered a predator species, D. quadriceps are in fact omnivores that generally scavenge dead animals, either whole or in pieces (Araújo \& Rodrigues 2006). Worker foraging is solitary and characterized by slow, winding movements outside the nest, with antenna tips touching the substrate (Araújo \& Rodrigues 2006).

Most of the Caatinga region is inhabited by D. quadriceps (Paiva \& Brandão 1995). This ecosystem is composed mainly of trees and low shrubs, many of which exhibit xerophytic characteristics, such as thorns and small leaves (Prado 2003). The Caatinga is made up of several different types of vegetation due to large-scale variations in climate related to the mountainous geography (Sampaio 1995). The availability of food resources for invertebrates in the Caatinga is subject to strong seasonal fluctuations (Araújo et al. 2010; Moura et al. 2006; Vasconcellos et al. 2010). Flowering, fruiting and leaf fall are some of the factors that undergo seasonal variation, and rain is the factor most responsible for this altered physiognomy (Barbosa et al. 2003; Griz \& Machado 2001; Machado et al. 1997; Sampaio 1995).

The aim of this study was to investigate seasonal variations in the extra-nest activity of $D$. quadriceps workers during a 24-month period in an area of Caatinga vegetation in Brazil. We investigated correlations between monthly worker abundance and climatic variables and potential prey availability. We looked for evidence of behavioral regulation based on environmental conditions that could characterize a seasonal pattern in foraging activity. Thus, we expected workers to avoid thermal and water stress, decreasing foraging activity at higher temperatures and lower humidity, and adjusting activity to food availability for efficient foraging.

\section{MATERIAL AND METHODS}

Information about the study area, data collection and sampling techniques is presented by Vasconcellos et al. (2010). Since $D$. quadriceps workers forage exclusively on leaf litter, they were caught only by pitfall traps, which were left open for three days a month. The number of $D$. quadriceps workers collected in pitfall traps was used to measure forag- ing activity. Foraging is the most common behavior displayed by $D$. quadriceps outside the nest, accounting for more than 90\% of extra-nest time (Araújo \& Rodrigues 2006). Thus, the worker capture rate in pitfall traps is mostly linked to their foraging activity in the ecosystem, whereas, if more workers are foraging outside the nest, the likelihood of more individuals falling into the pitfall traps increases (Dunn et al. 2007).

The Kruskal-Wallis $(\mathrm{H})$ non-parametric ANOVA test was used to determine if the abundance of $D$. quadriceps workers varied significantly over the course of the 24-month collection period. The number of $D$. quadriceps workers collected each month was correlated (using Spearman's correlation) with total monthly rainfall $(\mathrm{mm})$, average monthly relative humidity $(\%)$ and average monthly temperature $\left({ }^{\circ} \mathrm{C}\right)$. Worker abundance was also related to total abundance of arthropods collected in the three types of traps and to abundance of their potential prey. For analysis purposes only the following arthropod taxa cited by Araújo \& Rodrigues (2006) as part of $D$. quadriceps diet were considered potential prey: Coleoptera, Diptera, Hemiptera, Hymenoptera, Lepidoptera, Orthoptera, Araneae, Chilopoda and Diplopoda. Non-parametric tests were used because the data did not exhibit normal distribution and homogeneity of variance. All tests were performed using Statistica 6.0 software.

\section{RESULTS}

A total of 1100 D. quadriceps workers were collected during the 24-month collection period. D. quadriceps abundance varied over the course of each year, with activity peaks occurring from May to August in both years of the study $\left(\mathrm{H}_{(23, \mathrm{~N}=144)}\right.$ $=62.83, \mathrm{P}<0.001$; Fig. 1). The number of workers collected in the month of greatest activity (May 2008) was more than ten times greater than that collected in the month of least activity (October 2008).

The abundance of $D$. quadriceps in the samples collected for this study was inversely correlated with temperature $\left(r_{s}=-0.52, \mathrm{P}<0.01\right)$. There was no correlation between $D$. quadriceps abundance and rainfall $\left(r_{s}=0.28, \mathrm{P}=0.188\right)$ or relative humidity $\left(r_{s}=0.40, \mathrm{P}=0.053\right)$. The abundance of $D$. quadriceps was positively related to potential prey abundance $\left(r_{s}=0.45, \mathrm{P}<0.05\right)$, but not to total arthropod abundance $\left(r_{s}=0.31, \mathrm{P}=0.140\right)$.

\section{DISCUSSION}

The extra-nest activity of $D$. quadriceps workers showed seasonal variations, with peak activity at the late rainy season and early dry season. Seasonal ant activity has been observed in high latitude regions (Cerdá \& Retana 1989; Domisch et al. 2009; Suwabe et al. 2009; Vogt et al. 2003), characterized by well-defined seasons, tropical rainforests (Basu 1997; Levings 1983), semiarid environments (Barrow \& Parr 2008), areas modified by anthropic action, such as pastures (Gove \& Majer 2006) and cultivated areas (Fotso 

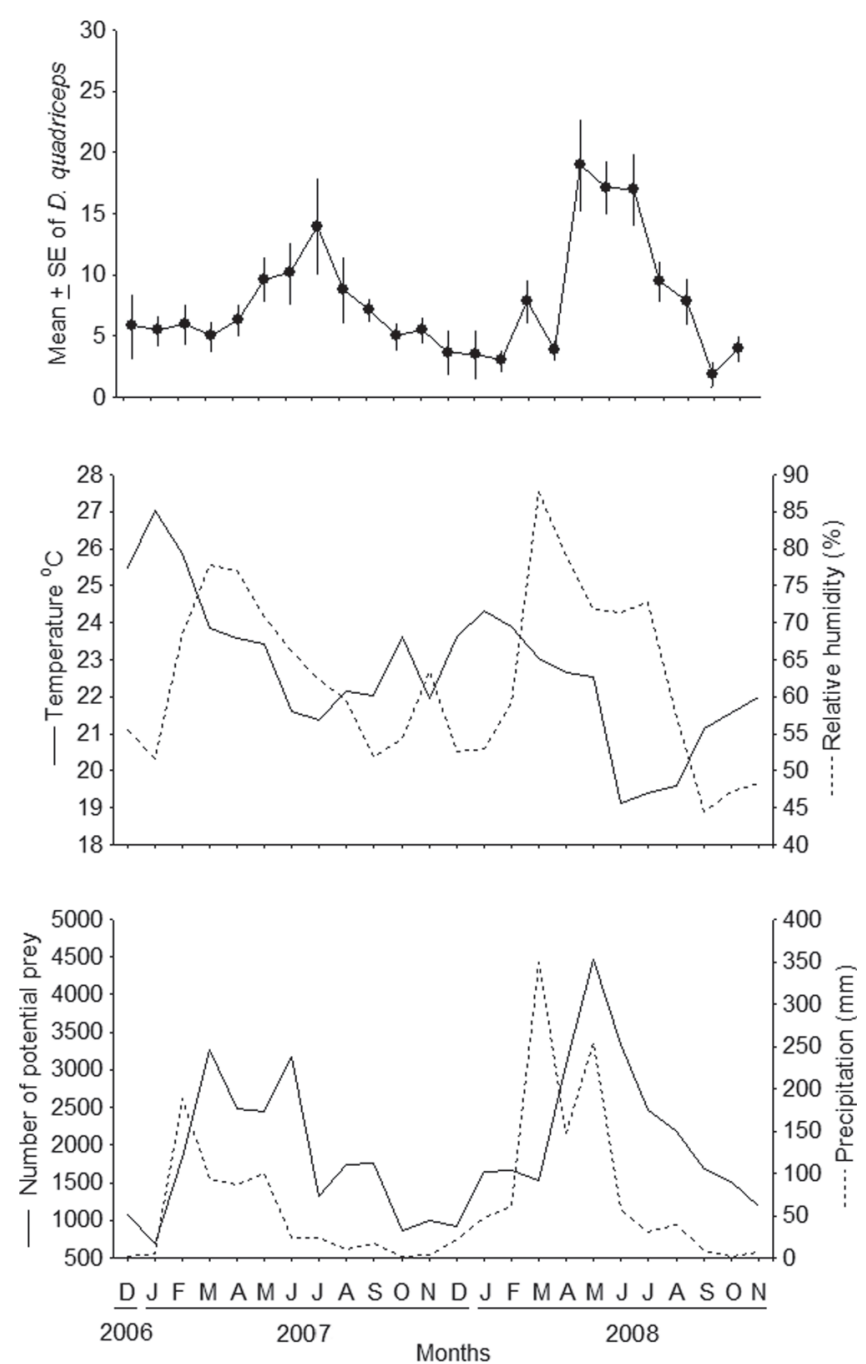

Fig. 1. Variation in extra-nest activity of Dinoponera quadriceps workers (a), temperature $\left({ }^{\circ} \mathrm{C}\right)$ and relative humidity $(\%)$ (b) potential prey and rainfall (mm) (c) over a 24-month period.

Kuate et al. 2008; Philpott et al. 2006). However, temporal variations in activity patterns vary with species, ecosystem and environmental factors.

The foraging pattern observed in D. quadriceps was associated with changes in temperature and food resource availability throughout the year. There was no relationship between D. quadriceps activity and rainfall or humidity, although these factors may be important for other organisms in the Caatinga. In a study conducted by Vasconcellos et al. (2010), rainfall and humidity were the factors most strongly related to insect abundance in the Caatinga. Analyzing the ant community in a tropical forest area in Panama, Levings (1983) showed that both seasonal activity variation and spatial variation were related to changes in humidity, with interannual differences associated to the rainfall of each year. In a study carried out by Fotso Kuate et al. (2008), in cassava-growing areas of Cameroon, daily variation in Anoplolepis tenella was positively related to humidity. In a subtropical area of Japan, Pheidole fervens, Pheidole noda and Paratrechina ryukyuensis also showed a positive relationship between activity and relative humidity (Suwabe et al. 2009). The daily activity of Cataglyphis iberica in the Iberian Peninsula was interrupted on rainy days, showing a negative relationship with humidity, luminosity and temperature being the most important factors (Cerdá \& Retana 1989).

Dinoponera quadriceps workers displayed the highest activity levels in months with milder temperatures and lowest in months with higher mean temperatures. Temperature changes, perceived by ants through thermosensitive sensilla located in their antennae (Ruchty et al. 2009), can limit foraging activity. Ant activity and abundance peak at times of lowest physical environmental stress (Levings 1983). High temperatures suppress foraging in species from different subfamilies, including Linepithema humile (Dolichoderinae) and Odontomachus chelifer (Ponerinae) (Abril et al. 2007; Orr \& Seike 1998; Raimundo et al. 2009); Anoplolepis tenella (Formicinae) (Fotso Kuate et al. 2008); Messor barbarus (Myrmicinae) (Detrain et al. 2000); Pogonomyrmex pronotalis, P. rastratus (Myrmicinae) and Ophthalmopone berthoudi (Ponerinae) (Peeters \& Crewe 1987; Pol \& Lopez de Casenave 2004). Within the Dinoponera genus, an inverse relationship between colony activity and temperature was also observed in $D$. gigantea in a secondary rainforest area (Fourcassié \& Oliveira 2002). Furthermore, D. gigantea workers were more active at dawn and dusk, and there is evidence that night-time foraging also occurs (Fourcassié \& Oliveira 2002). In D. longipes, activity is primarily nocturnal, possibly so that workers can avoid higher daytime temperatures (Morgan 1993).

Another determining factor for seasonal variations in the foraging activity of $D$. quadriceps was potential prey availability. The increased foraging activity observed in D. quadriceps when more food is available also occurs in other ant species, in both carnivores, such as Gnamptogenys moelleri (Cogni \& Oliveira 2004), Ophthalmopone berthoudi (Peeters $\&$ Crewe 1987) and Odontomachus chelifer (Raimundo et al. 2009), and seed collectors, such as Pogonomyrmex rastratus, $P$. inermis and $P$. mendozanus (Pol et al. 2011). These results corroborate the idea that ants adjust their activity according to food availability in the ecosystem, decreasing foraging when little food is available. In eleven ant communities composed of twenty different species in a desert environment in the United States, ants used temperature as an environmental cue to make this adjustment for prey availability (Bernstein 1979). The temperature range of greatest foraging activity is associated to the season with greatest food abundance for a given species (Bernstein 1979). However, the use of an adjustment mechanism independent of temperature is also possible, through a social facilitation process. The return to the nest of successful foragers may induce other foragers to set out, but not to a specific site (Peeters \& Crewe 1987; Raimundo et al. 2009; Schafer et al. 2006). The stimulation of inactive foragers by the return of successful foragers, as occurs in Pogonomyrmex barbatus (Schafer et al. 2006) and Odontamachus chelifer (Raimundo et al. 2009), 
is sufficient for the adjustment of foraging intensity based on changes in food availability. When food availability declines, the number of successful foragers returning to the nest is lower, as is the departure rate of additional foragers (Schafer et al. 2006).

The absence of a relationship between $D$. quadriceps activity and total abundance of soil arthropods and the existence of a positive relationship between some orders and specific classes of these organisms indicates a preference for certain ecosystem prey, as confirmed by Araújo \& Rodrigues (2006) in an area of secondary Atlantic Forest in the Brazilian northeast. Diet similarity had already been observed by Fourcassié \& Oliveira (2002) and Araújo \& Rodrigues (2006) in the genus Dinoponera, specifically $D$. quadriceps and D. gigantea. This also seems to occur in populations of $D$. quadriceps that inhabit contrasting ecosystems, such as tropical rainforest and the Caatinga.

The existence of more favorable foraging periods during the year, with a combination of lower temperature and increased potential prey abundance, may lead to seasonal size variation in $D$. quadriceps colonies. Although colony composition throughout the year was not assessed in this study, Paiva \& Brandão (1995) found seasonal variations in D. australis offspring associated to the time of year in which foraging activity increases. In D. quadriceps, Dantas de Araújo et al. (1990a) reported a possible male production at a particular time of the year. Dada obtained by Vasconcellos et al. (2004) indicate continuous and asynchronous male production among colonies, not related to climatic factors. However, worker production in the Caatinga may not follow the same pattern, given that these studies were conducted in Atlantic Forest areas with greater climatic predictability (Formigoni et al. 2011). Barrow \& Parr (2008) analyzed three types of habitat in a semiarid region of Australia, observing temporal variation differences in ant abundance related to the degree of seasonal fluctuation in climatic conditions and food availability in each type of environment.

In summary, our results showed that the activity of $D$. quadriceps in the Caatinga exhibits a seasonal pattern that persists over years, is concentrated between May and August, and is influenced negatively by temperature and positively by prey availability. Moreover, $D$. quadriceps showed a behavioral response in syntony with seasonal fluctuations in the Caatinga, adjusting their foraging activity when there is a combination of lower air temperature and increased prey availability in the ecosystem. On the other hand, the is a need for supplementary studies that assess the relationship between peak foraging activity and size fluctuations in $D$. quadriceps colonies between the dry and rainy seasons in the Caatinga.

\section{ACKNOWLEDGMENTS}

The authors are grateful to the Braz family, owners of the RPPN-Fazenda Almas, for logistical support during the study. This research was supported by CNPq/PELD $(520062 / 2006-0)$.

\section{REFERENCES}

Abril, S.; J. Oliveras \& C. Gómez. 2007. Foraging activity and dietary spectrum of the Argentine ant (Hymenoptera: Formicidae) in invaded natural areas of the northeast Iberian Peninsula. Environmental Entomology 36: 1166-1173.

Araújo, A. \& Z. Rodrigues. 2006. Foraging behavior of the queenless ant Dinoponera quadriceps Santschi (Hymenoptera: Formicidae). Neotropical Entomology 35: 159-164.

Araújo, C. S.; D. M. Candido; H. F. P. Araújo; S. C. Dias \& A. Vasconcellos. 2010. Seasonal variations in scorpion activities (Arachnida: Scorpiones) in an area of Caatinga vegetation in northeastern Brazil. Zoologia 27: $372-376$.

Barbosa, D. C. de A.; M. C. de A. Barbosa \& L. C. M. de Lima. 2003. Fenologia das espécies lenhosas da Caatinga, p. 657-694. In: I. R. Leal; M. Tabarelli \& J. M. C. da Silva (eds.). Ecologia e Conservação da Caatinga. Recife, Editora Universitária da UFPE, 804 p.

Barrow, L. \&C. L. Parr. 2008. A preliminary investigation of temporal patterns in semiarid ant communities: variation with habitat type. Austral Ecology 33: 653-662.

Basu, P. 1997. Seasonal and spatial patterns in ground foraging ants in a rain forest in the Western Ghats, India. Biotropica 29: 489-500.

Beckers, R.; S. Goss; J. L. Deneubourg \& J. M. Pasteels. 1989. Colony size, communication and ant foraging strategy. Psyche 96: 239-256.

Bernstein, R. A. 1979. Schedules of foraging activity in species of ants. Journal of Animal Ecology 48: 921-930.

Cerdá, X. \& J. Retana. 1989. Influencia de los factores ambientales sobre la actividad diaria de recolección de la hormiga Cataglyphis iberica (Em.) (Hym.: Formicidae). Anales de Biología 15: 75-82.

Cogni, R. \& P. S. Oliveira. 2004. Patterns in foraging and nesting ecology in the neotropical ant, Gnamptogenys moelleri (Formicidae, Ponerinae). Insectes Sociaux 51: 123-130.

Dantas de Araújo, C. Z.; D. Fresneau \& J. -P. Lachaud. 1990a. Données biologiques sur la fondation des colonies de Dinoponera quadriceps (Hymenoptera, Formicidae). Actes des Colloques Insectes Sociaux 6: 281-286.

Dantas de Araújo, C. Z.; J.-P. Lachaud \& D. Fresneau. 1990b. Le système reproductif chez une ponérine sans reine: Dinoponera quadriceps Santschi. Behavioural Processes 22: 101-111.

Detrain, C.; O. Tasse; M. Versaen \& J. M. Pasteels. 2000. A field assessment of optimal foraging in ants: trail patterns and seed retrieval by the European harvester ant Messor barbarous. Insectes Sociaux 47: 56-62.

Domisch, T.; L. Finér; S. Neuvonen; P. Niemelä; A. C. Risch; J. Kilpeläinen; M. Ohashi \& M. F. Jurgensen. 2009. Foraging activity and dietary spectrum of wood ants (Formica rufa group) and their role in nutrient fluxes in boreal forests. Ecological Entomology 34: 369-377.

Dunn, R. R.; C. R. Parker \& N. J. Sanders 2007. Temporal patterns of diversity: assessing the biotic and abiotic controls on ant assemblages. Biological Journal of the Linnean Society 91: 191-201.

Formigoni, M. de H.; A. C. Xavier \& J. S. de S. Lima. 2011. Análise temporal da vegetação na região do Nordeste através de dados EVI do MODIS. Ciência Florestal 21: 1-8.

Fotso Kuate, A.; M. Tindo; R. Hanna; M. Kenne \& G. Goergen. 2008. Foraging activity and diet of the ant, Anoplolepis tenella Santschi (Hymenoptera: Formicidae), in southern Cameroon. African Entomology 16: 107-114.

Fourcassié, V. \& P. S. Oliveira. 2002. Foraging ecology of the giant Amazonian ant Dinoponera gigantea (Hymenoptera, Formicidae, Ponerinae): activity schedule, diet and spatial foraging patterns. Journal of Natural History 36: 2211-2227.

Gove, A. D. \& J. D. Majer. 2006. Do isolated trees encourage arboreal ant foraging at ground-level? Quantiûcation of ant activity and the inûuence of season, in Veracruz, Mexico. Agriculture, Ecosystems and Environment 113: 272-276.

Griz, L. M. S. \& I. C. S. Machado. 2001. Fruiting phenology and seed dispersal syndromes in the caatinga, a tropical dry forest in the northeast of Brazil. Journal of Tropical Ecology 17: 303-321. 
Hart, A.G. \&F. L. W. Ratnieks. 2005. Crossing the taxonomic divide: conflict and its resolution in societies of reproductively totipotent individuals. Journal of Evolutionary Biology 18: 383-395.

Kempf, W. W. 1971. A preliminary review of the ponerine ant genus Dinoponera Roger (Hymenoptera: Formicidae). Studia Entomologica 14: 369-394.

Levings, S. C. 1983. Seasonal, annual, and among-site variation in the ground ant community of a deciduous tropical forest: some causes of patchy species distributions. Ecological Monographs 53: 435-455.

Machado, I. C. S.; L. M. Barros \& E. V. S. B. Sampaio. 1997. Phenology of Caatinga Species at Serra Talhada, PE, Northeastern Brazil. Biotropica 29: $57-68$

Monnin, T.; C. Malosse \& C. Peeters. 1998. Solid-phase microextraction and cuticular hydrocarbon differences related to reproductive activity in queenless ant Dinoponera quadriceps. Journal of Chemical Ecology 24: 473-490.

Monnin, T. \& C. Peeters. 1998. Monogyny and regulation of worker mating in the queenless ant Dinoponera quadriceps. Animal Behaviour 55: 299-306.

Monnin, T. \& C. Peeters. 1999. Dominance hierarchy and reproductive conflicts among subordinates in a monogynous queenless ant. Behavioral Ecology 10: 323-332.

Monnin, T. \& F. L. W. Ratnieks 1999. Reproduction versus work in queenless ants: when to join a hierarchy of hopeful reproductives? Behavioral Ecology and Sociobiology 46: 413-422.

Monnin, T.; F. L. W. Ratnieks \& C. R. F. Brandão. 2003. Reproductive conflict in animal societies: hierarchy length increases with colony size in queenless ponerine ant. Behavioral Ecology and Sociobiology 54: 71-79.

Monnin, T.; F. L. W. Ratnieks; G. R. Jones \& R. Beard. 2002. Pretender punishment induced by chemical signalling in a queenless ant. Nature 419: $61-65$.

Morgan, R. C. 1993. Natural history notes and husbandry of the Peruvian giant ant Dinoponera longipes (Hymenoptera: Formicidae). SASI-ITAG Invertebrates in Captivity Conference Proceedings, p. 140-151.

Moura, F. M. S.; A. Vasconcellos; V. F. P. Araújo \& A. G. Bandeira. 2006. Seasonality in foraging behaviour of Constrictotermes cyphergaster (Termitidae, Nasutitermitinae) in the Caatinga of northeastern Brazil. Insectes Sociaux 53: 472-479.

Orr, M. R. \& S. H. Seike. 1998. Parasitoids deter foraging by Argentine ants (Linepithema humile) in their native habitat in Brazil. Oecologia 117: $420-425$

Paiva, R. V. S. \& C. R. F. Brandão. 1995. Nests, worker population, and reproductive status of workers, in the giant queenless ponerine ant Dinoponera Roger (Hymenoptera Formicidae). Ethology Ecology \& Evolution 7: 297-312.

Peeters, C. \& R. Crewe. 1987. Foraging and recruitment in ponerine ants: solitary hunting in the queenless Ophthalmopone berthoudi
(Hymenoptera: Formicidae). Psyche 94: 201-214.

Peeters C.; T. Monnin \& C. Malosse. 1999. Cuticular hydrocarbons correlated with reproductive status in a queenless ant. Proceedings of the Royal Society of London B 266: 1323-1327.

Philpott, S. M.; I. Perfecto \& J. H. Vandermeer. 2006. Effects of management intensity and season on arboreal ant diversity and abundance in coffee agroecosystems. Biodiversity and Conservation 15: 139-155.

Pol, R. \& J. Lopez deCasenave. 2004. Activity patterns of harvester ants Pogonomyrmex pronotalis and Pogonomyrmex rastratus in the central Monte desert, Argentina. Journal of Insect Behavior 17: 647-661.

Pol, R. G.; J. Lopez de Casenave \& G. I. Pirk. 2011. Inûuence of temporal ûuctuations in seed abundance on the foraging behaviour of harvester ants (Pogonomyrmex spp.) in the central Monte desert, Argentina. Austral Ecology 36: 320-328.

Prado, D. E. 2003. As Caatingas da América do Sul, p. 3-74. In: I. R. Leal; M. Tabarelli \& J. M. C. da Silva (eds).Ecologia e Conservação da Caatinga. Recife, Editora Universitária da UFPE, 804 p.

Raimundo, R. L. G.; A. V. L. Freitas \& P. S. Oliveira. 2009. Seasonal patterns in activity rhythm and foraging ecology in the neotropical forestdwelling ant, Odontomachus chelifer (Formicidae: Ponerinae). Annals of the Entomological Society of America 102: 1151-1157.

Ruchty, M.; R. Romani; L. S. Kuebler; S. Ruschioni; F. Roces; N. Isidoro \& C. J. Kleineidam. 2009. The thermo-sensitive sensilla coeloconica of leaf-cutting ants (Atta vollenweideri). Arthropod Structure \& Development 38: 195-205.

Sampaio, E. V. S. B. 1995. Overview of the Brazilian Caatinga, p. 35-63. In: S. H. Bullock; H. A. Mooney \& E. Medina (eds). Seasonally Dry Tropical Forests. Cambridge, Cambridge University Press, 450 p.

Schafer, R. J.; S. Holmes \& D. M. Gordon. 2006. Forager activation and food availability in harvester ants. Animal Behaviour 71: 815-822

Suwabe, M.; H. Ohnishi; T. Kikuchi; K. Kawara \& K. Tsuji. 2009. Difference in seasonal activity pattern between non-native and native ants in subtropical forest of Okinawa Island, Japan. Ecological Research 24: 637-643.

Traniello, J. F. A. 1989. Foraging strategies of ants. Annual Review of Entomology 34: 191-210.

Vasconcellos, A; G. G. Santana \& A. K. Souza. 2004. Nest spacing and architecture, and swarming of males of Dinoponera quadriceps (Hymenoptera, Formicidae) in a remnant of the Atlantic Forest in Northeast Brazil. Brazilian Journal of Biology 64: 357-362.

Vasconcellos, A.; R. Andreazze; A. M. Almeida; H. F. P. Araujo; E. S. Oliveira \& U. Oliveira. 2010. Seasonality of insects in a semi-arid Caatinga of northeastern Brazil. Revista Brasileira de Entomologia 54: 471-476.

Vogt, J. T.; W. A. Smith; R. A. Grantham \& R. E. Wright. 2003. Effects of temperature and season on foraging activity of red imported fire ants (Hymenoptera: Formicidae) in Oklahoma. Environmental Entomology 32: $447-451$ 